\title{
PENGARUH ADVERSITY QUOTIENT TERHADAP MOTIVASI BERPRESTASI PADA SISWA CERDAS ISTIMEWA
}

\author{
Rini Sugiarti 1, Annisa Nurlaili' ${ }^{2}$ Umi Farida Febriani ${ }^{3}$ \\ 1,2Fakultas Psikologi, Universitas Semarang \\ ${ }^{3}$ Fakultas Psikologi, Universitas Muhammadiyah Surakarta

\section{riendoe@usm.ac.id}

\begin{abstract}
This study aims to find out the effect of adversity quotient on achievement motivation in gifted students empirically. The hypothesis proposed in this study is that there is an adversity quotient effect on achievement motivation in gifted students. The higher the adversity quotient is, the higher the achievement motivation in superior class students is, and vice versa. The subjects in this study were 60 gifted students of MTs Negeri 1 Semarang consisting of 30 superior science class VIII A students and 30 leading religious class VIII J students. The sampling technique used was saturated sampling. The measuring instrument used in this study was the scale of achievement motivation in the superior class students and the adversity quotient scale. Data analysis were carried out using simple regression analysis techniques and showed by $F$ of 68,388 and $p$ of $0.000(p<0.05)$. the contribution percentage of the variable adversity quotient and achievement motivation is $54,1 \%$ while the remaining 45,9\% is influenced or explained by other variables that are not used. From the results of this study it can be concluded that the proposed hypothesis can be accepted.
\end{abstract}

Key words : Adversity Quotient, Achievement Motivation, Gifted Students.

Abstrak. Penelitian ini bertujuan untuk menguji secara empiris pengaruh adversity quotient terhadap motivasi berprestasi pada siswa cerdas istimewa. Hipotesis yang diajukan dalam penelitian ini adalah terdapat pengaruh adversity quotient terhadap motivasi berprestasi pada siswa cerdas istimewa. Subjek dalam penelitian ini berjumlah 60 siswa cerdas istimewa di kelas unggulan MTs Negeri 1 Semarang, yang terdiri atas 30 siswa kelas VIII A unggulan sains dan 30 siswa kelas VIII J unggulan agama. Teknik pengambilan sampel yang digunakan adalah sampling jenuh. Alat ukur dalam penelitian ini adalah skala motivasi berprestasi pada siswa cerdas istimewa dan skala adversity quotient. Analisis data dilakukan dengan menggunakan teknik analisis regresi sederhana dan menunjukkan bahwa terdapat pengaruh adversity quotient terhadap motivasi berprestasi pada siswa cerdas istimewa yang ditunjukkan dengan nilai F sebesar 68, 388 dan $\mathrm{p}$ sebesar $0,000(\mathrm{p}<0,05)$. Sumbangan variabel adversity quotient dan motivasi berprestasi sebesar 54,1\% sedangkan sisanya 45,9\% dipengaruhi oleh variabel lain yang tidak digunakan. Dari hasil penelitian ini dapat ditarik kesimpulan bahwa hipotesis yang diajukan dapat diterima.

Kata Kunci : Adversity Quotient, Motivasi Berprestasi, Siswa Cerdas Istimewa.

\section{Pendahuluan}

Kemajuan pembangunan semakin pesat terutama bidang pendidikan, yang secara tidak langsung menuntut siswa untuk mengembangkan potensi yang ada dalam dirinya. Pengembangan potensi diperlukan untuk menghadapi tantangan dan persaingan dengan persiapan yang sudah diakukan sebelumnya. Salah satu usaha dalam potensi tersebut 
diwujudkan dengan adanya program kelas unggulan. Pendidikan unggulan menjadi kebutuhan mengingat banyaknya potensi anak bangsa yang perlu mendapatkan pelayanan khusus. Keanaekaragaman potensi anak didik membutuhkan pembinaan yang berbeda dan tidak dapat diberikan perlakuan yang sama. Pendidikan yang ada disekolah formal sesuai dengan anak-anak normal pada umunya, akan tetapi terhadap anak yang unggul juga diberikan pendidikan yang unggul juga.

Kelas unggulan adalah kelas khusus untuk siswa-siswa yang memiliki kemampuan, bakat, keterampilan, kreativitas serta intelegensi yang lebih daripada siswa yang lainnya dan kemudian mendapat program pengajaran yang berbeda dalam meningkatkan kelebihannya tersebut (Khusnayain,2015:34). Program kelas unggulan adalah program khusus untuk mengelompokkan siswa berdasarkan prestasi yang tinggi, dimana siswa dituntut agar dapat mencapai prestasi lebih baik dari siswa kelas reguler. Berbeda dengan kelas akselerasi yang berfokus pada metode percepatan bagi siswa yang memiliki kemampuan akademik di atas rata-rata, maka kelas unggulan mengelompokkan siswa yang memiliki kemampuan akademik di atas rata-rata dengan memperbanyak pada kurikulum bagi kelas unggulan dan sarana serta prasarana pendukung kegiatan belajar mengajar.Hawadi(dalam Ahyani,2015:241).

Tujuan penerapan kelas unggulan diantaranya untuk mengembangkan dan meningkatkan kualitas pendidikan, menghasilkan sumber daya manusia yang berkualitas, meningkatkan kemampuan dan pengetahuan tenaga pendidik, mengembangkan potensi yang ada di Sekolah, meningkatkan kemampuan untuk menghadapi persaingan di dunia pendidikan dengan menciptakan keunggulan kompetitif. Proses input siswa kelas unggulan melalui beberapa tahapan seleksi akademis dan non akademis.

Siswa kelas unggulan wajib memiliki nilai rata - rata yang tinggi setiap semester dari seluruh jumlah siswa dalam satu kelas, maka tidak menutup kemungkinan akan terjadi eliminasi pada setiap kenaikan kelas. Diharapkan seluruh siswa kelas unggulan memiliki motivasi untuk berprestasi agar dapat memenuhi tujuan diselenggarakannya program kelas unggulan. Berdasarkan hasil wawancara empat siswa kelas unggulan, siswa mengaku merasa lebih berat dibandingkan dengan kelas regular karena banyaknya tugas baik dari akademik maupun non akademik, serta adanya persaingan yang cukup tinggi antar teman satu kelas.

Salah satu keberhasilan siswa dalam pendidikan ditunjukkan dengan prestasi akademik yang dimiliki. Motivasi berprestasi memberikan pengaruh yang besar terhadap pencapaian yang diperoleh seseorang. Albert (2015:34) menyatakan bahwa motivasi 


\section{Philanthropy Journal of Psychology \\ Vol 4 Nomor 1 (2020), 82-92 \\ ISSN 2580-6076 (Print), ISSN 2580-8532 (Online)}

berprestasi membantu untuk menemukan perubahan respon, perubahan diri dan penerapan dalam relasi antara stimulus dan respon. Prinsisp dalam kegiatan belajar adalah sesorang akan berhasil dalam beajar, jika oeang tersebut mempunyai keiginan untuk belajar.Keinginan inilah yang disebut dengan motivasi berprestasi. Menurut Mc Clelland (dalam Jamaris, 2013:175) dalam $n$-ach motivasi berprestasi individu berusaha mencapai prestasi dari kegiatan yang dilakukannya dan berusaha mengatasi hambatan yang mengalangi dalam mencapai prestasi. Individu yang memiliki $n$-ach berusaha menerima saran yang dijadikan masukan dalam usahanya mencapai prestasi sesuai denagn tujuan yang telah direncanakannya. Individu yang memiliki $n$-ach yang tinggi berusaha untuk menjadi lebih baik atau lebih berprestasi.

Menurut Mc.Clelland (dalam Mangkunegara, 2010:19) motivasi berprestasi dapat diartikan sebagai suatu dorongan dalam diri seseorang untuk mengerjakan suatu kegiatan atau tugas dengan sebaik - baiknya agar mencapai prestasi dengan predikat yang memuasakan. Motivasi berprestasi adalah kondisi fisiologis dan psikologis (kebutuhan berprestasi) yang terdapat di dalam diri siswa yang mendorongnya untuk melakukan aktivitas tertentu guna mencapai suatu tujuan tertentu (berprestasi setinggi mungkin). (Djaali, 2015:103). Menurut Hare dan Lamb (dalam Djaali, 2015:103) motivasi berprestasi merupakan motivasi yang berhubungan dengan pencapaian beberapa standard kepandaian atau standard keahlian. Sementara itu Heckhausen (dalam Djaali, 2015 : 103) juga mengemukakan bahwa motivasi berprestasi adalah suatu keinginan yang ada dalam diri siswa yang berjuang dan berusaha untuk meningkatkan prestasi. Berdasarkan beberapa pendapat tokoh diatas dapat disimpulkan bahwa motivasi berprestasi adalah dorongan/keinginan yang ada dalam diri siswa untuk melakukan kegiatan yang berhubungan dengan proses belajar dalam meraih keberhasilan yang tinggi dalam prestasi dan berusaha mengatasai masalah yang menghalangi.

Salah satu faktor internal yang mempengaruhi motivasi berprestasi, yaitu kecerdasan adversitas (Adversity Quotient). Keberhasilan individu tidak hanya ditentukan pada tingkat $I Q$ dan $E Q$ saja, tetapi Adversity Quotient (kecerdasan adversitas). Bagaimana cara individu mengatasi masalahnya, merupakan cerminan dari Adversity Quotient, Adversity Quotient adalah pola yang tepat yang dapat mengukur cara individu menanggapi segala bentuk dan intensitas masalah, bagaimana individu mampu bertahan menghadapi masalah dan mampu untuk mengatasinya (Patricia, Zamralita dan Ninawati, 2009:66). Farelin dan Erin (2017:48) menyatakan bahwa individu dapat mengembangkan potensi yang dimilikinya serta dapat memotivasi diri untuk mengahadapi permasalahan yang ada 
dan dapat mencapai prestasi yang maksimal . Saat individu memiliki $A Q$ yang tinggi maka akan mampu memecahkan masalah yang diahadapi, sehingga motivasi berpresatasi akan mucul untuk mencapai suatau prestasi yang ingin diraih.

Menurut Benbow dan Lubinski (dalam Wijilestari, 2013:103) siswa yang memiliki kemampuan dan mempunyai motivasi tinggi, akan lebih cepat memperoleh pengetahuan dan keterampilan dalam mengikuti program akselerasi (unggulan). Ormrod (dalam Wijilestari, 2013:104) mengatakan bahwa siswa cerdas dan berbakat istimewa memiliki motivasi yang tinggi ketika menghadapi tugas yang menanatang, meraka juga mempunyai konsep diri yang baik, memiliki fleksibel dalam berfikir dan bertindak untuk menggunakan pendekatan dalam belajar.

Pada dasarnya setiap individu mempunyai permasalan dalam menjalankan hidupnya. Dalam menyikapi permasalah tersebut berbeda-beda. Ada individu yang gagal dalam menghadapi kesulitan, namun ada juga individu yang berhasil dalam menghadapi kesulitan. Ketika gagal menghadapi kesulitan dalam hidupnya, akan cenderung kurang suskes, namun akan berlaku sebaliknya jika individu berhasil menghadapi kesulitan maka individu akan mendapatkan kesuksesan. Di antara salah satu faktor yang mempengaruhi kesuksesan individu yakni kecerdasan adversity. Kecerdasan adversity pertama kali diperkenalkan oleh Paul G. Stoltz yang disusun berdasarkan hasil riset lebih dari 500 kajian di seluruh dunia. Kecerdasan adversity ini merupakan terobosan penting dalam pemahaman tentang apa yang dibutuhkan untuk mencapai kesuksesan.

Adversity quotient (AQ) dapat disebut dengan kecerdasan adversitas, Menurut Stoltz (2000:8) Adversity Quotient merupakan suatu kemampuan seseorang dalam mengatasi kesulitan dan mengubah kesulitan dalam meraih kesuksesan. AQ adalah pengetahuan baru untuk memahami dan meningkatkan kesuksesan. AQ adalah tolok ukur untuk mengetahui kadar respons terhadap kesulitan dan merupakan peralatan praktis untuk memperbaiki respons-respons terhadap kesulitan. AQ pada intinya membahas tentang ketahanan seseorang untuk berusaha mencapai sesuatu yang paling tinggi, menurut ukuran kemampuan yang dimiliki dan dilakukan dengan terus-menerus. Sopiatin dan Sahrani (2011:152). AQ adalah kemampuan individu untuk bertahan menghadapi kesulitan dan kemampuan untuk mengatasinya. Sopiatin dan Sahrani (2011:152). Istilah "adversity" lebih sering diterjemahkan dengan "kemalangan". Kata tersebut berakar dari kata "malang" yang berarti "sesuatu kondisi yang merujuk pada keadaan yang selalu buruk dan nasib yang tidak menguntungkan, biasanya dalam jangka waktu yang agak lama". Menurut Adleri (dalam Amir dan Risnawati, 2016:176) Adversity quotient 
merupakan kompensasi (striving force as compensation) dimana manusia memiliki daya juang sejak lahir, dan mempunyai potensi berjuang untuk mencapai tujuan yang merupakan kompensasi dari rasa inferior (rendah diri), sehingga daya juang harus diasah dan dikembangkan, agar jiwa manusia menjadi sehat dan seimbang. Adleri juga mengatakan bahwa manusia dapat berjuang untuk kepentingan pribadinya dan lingkungannya. Stoltz (2000:9) Adversity quotient memiliki konsep yang terwujud dalam tiga bentuk yaitu (1) AQ adalah suatu kerangka kerja konseptual yang baru untuk memahami dan meningkatkan semua segi kesuksesan. (2) AQ adalah suatu ukuran untuk mengetahui respons terhadap kesulitan. (3) AQ adalah serangkaian peralatan yang memiliki dasar ilmiah untuk memperbaiki respons terhadap kesulitan. Diharapkan dengan adanya Adversity Quotient pada siswa kelas unggulan, dapat meningkatkan keyakinan dalam diri untuk memiliki motivasi berprestasi yang tinggi.

Kenyataannya, masih terdapat siswa kelas unggulan yang memiliki motivasi berprestasi rendah, meskipun memiliki keyakinan untuk bertahan menghadapi hambatan dan kesulitan yang ada didalam kelas unggulan. Berdasarkan dari data - data yang telah di uraikan diatas, maka dari itu peneliti tertarik untuk meneliti mengenai apakah ada pengaruh Adversity Quotient terhadap motivasi berprestasi pada siswa kelas unggulan MTs N 1 Semarang ? Penelitian ini dilakukan untuk menguji secara empiris pengaruh Adversity Quotient terhadap motivasi berprestasi pada siswa kelas unggulan MTs N 1 Semarang.

\section{Metode}

Subjek dalam penelitian ini adalah 60 siswa yang terdiri atas kelas VIII A yang berjumlah 30 siswa dan kelas VIII Jyang berjumlah 30 siswa. Teknik pengambilan sampel yang digunakan adalah sampling jenuh yang merupakan metode penetapan subjek yang dijadikan penelitian berdasarkan pada kriteria. Adapaun ktiteria dari penetapan subjek subjek Karakteristik populasi dalam penelitian ini adalah Siswa kelas unggulan sains dan agama di MTs N 1 Semarang, Siswa kelas VIII unggulan yang terdiri dari dua kelas yaitu, kelas A dan kelas J.

Alat pengumpulan data yang digunakan adalah Skala Motivasi Berprestasi pada Siswa Kelas Unggulan dan Skala Adversity quotient. jenis skala yang digunakan dala penelitian ini menggunakan skala likert. Teknik analisis data yang digunakan untuk menguji pengaruh adversity quotient sebagai variabel bebas dengan motivasi berprestasi 
pada siswa kelas unggulan sebagai variabel tergantung, dengan menggunakan rumus analisis regresi sederhana

\section{Hasil}

Berdasarkan uji asumsi yang dilakukan, yaitu uji normalitas yang menyatakan bahwa data berdistribusi normal dan uji linieritas data tersebut ada hubungan linier, maka hal ini memenuhi syarat untuk melalukan uji hipotesis dengan menggunakan teknik Analisis Regresi menggunakan bantuan SPSS (Statistical Packages For Social Science) versi 23. Adapun hasil analisis regresi dapat dilihat dari tabel berikut :

\begin{tabular}{|c|c|c|c|c|c|c|c|c|c|}
\hline & \multirow[b]{3}{*}{$\mathrm{R}$} & \multirow[b]{3}{*}{$\begin{array}{c}\mathrm{R} \\
\text { Square }\end{array}$} & \multirow[b]{3}{*}{$\begin{array}{l}\text { Adjusted } \\
\text { R Square }\end{array}$} & \multicolumn{5}{|c|}{ Model Summary ${ }^{\mathrm{b}}$} & \\
\hline \multirow[b]{2}{*}{ Model } & & & & Std. & \multicolumn{5}{|c|}{ Change Statistics } \\
\hline & & & & $\begin{array}{l}\text { Error of } \\
\text { the } \\
\text { Estimate }\end{array}$ & $\begin{array}{c}\text { R Square } \\
\text { Change }\end{array}$ & $\begin{array}{c}\mathrm{F} \\
\text { Change }\end{array}$ & df1 & df2 & $\begin{array}{c}\text { Sig. F } \\
\text { Change }\end{array}$ \\
\hline 1 &, $736^{\mathrm{a}}$ & ,541 & ,533 & 7,555 & ,541 & 68,388 & 1 & 58 & ,000 \\
\hline
\end{tabular}

a. Predictors:

(Constanadversity_quotient

b. Dependent Variable: motivasi_berprestasi

Hasil analisis data yang diperoleh bahwa $F=68,388$ dan $p=0,000(p \leq 0,05)$ yang berarti terdapat pengaruh adversity quotient terhadap motivasi berprestasi pada siswa kelas unggulan. Semakin tinggi Adversity Quotient maka semakin tinggi juga Motivasi Berprestasi pada Siswa Kelas Unggulan, begitu sebaliknya.

Sumbangan efektif variabel independen penelitian yaitu adversity quotient mempengaruhi motivasi berprestasi sebesar 54,1\%, sisanya 45,9\% dipengaruhi oleh variabel lain seperti faktor biologis, sikap, minat, bakat, dll. Hasil penelitian ini sesuai dengan hipotesis yang diajukan, bahwa terdapat pengaruh adversity quotient terhadap motivasi berprestasi pada siswa kelas unggulan.

\section{Diskusi}

Hasil penelitian ini menunjukan bahwa terdapat pengaruh adversity quotient terhadap motivasi berprestasi pada siswa kelas unggulan dengan mengunakan analisis regresi diperoleh hasil $F=68,388$ dan $p=0,000(p \leq 0,05)$, artinya Semakin tinggi 
Philanthropy Journal of Psychology

Vol 4 Nomor 1 (2020), 82-92

ISSN 2580-6076 (Print), ISSN 2580-8532 (Online)

Adversity Quotient maka semakin tinggi juga Motivasi Berprestasi pada Siswa Kelas Unggulan, begitu sebaliknya.

Diterimanya hipotesis dalam penelitian ini menunjukan bahwa adversity quotient dapat digunakan untuk meningkatkan motivasi berprestasi pada siswa kelas unggulan. Sebagaimana halnya yang dikemukakan oleh Hamdani (2011:139) bahwa motivasi berprestasi dipengaruhi oleh dua faktor, yaitu faktor dari dalam (intern) yang meliputi kecerdasan, faktor jasmaniah atau biologis, sikap, minat, bakat dan faktor dari luar (ekstern) yang meliputi keadaan keluarga, keadaan sekolah, lingkungan masyarakat. Adversity quotient merupakan bentuk kecerdasan yang menyebabkan kesuksesan seseorang dalam menghadapi sebuah kesulitan atau kegagalan dalam kehidupannya serta mengubah kesulitan atau kegagalan itu menjadi peluang dan tantangan yang harus diselesaikan supaya tidak menjadi penghalang dalam mencapai kesuksesan. Menurut Mc Clelland (dalam Jamaris, 2013:175) dalam $n$-ach motivasi berprestasi individu berusaha mencapai prestasi dari kegiatan yang dilakukannya dan berusaha mengatasi hambatan yang mengalangi dalam mencapai prestasi.

Program kelas unggulan adalah program khusus untuk mengelompokkan siswa berdasarkan prestasi yang tinggi, dimana siswa dituntut agar dapat mencapai prestasi lebih baik dari siswa kelas reguler. Berbeda dengan kelas akselerasi yang berfokus pada metode percepatan bagi siswa yang memiliki kemampuan akademik di atas rata-rata, maka kelas unggulan mengelompokkan siswa yang memiliki kemampuan akademik di atas rata-rata dengan memperbanyak pada kurikulum bagi kelas unggulan dan didukung sarana serta prasarana pendukung kegiatan belajar mengajar.Hawadi(dalam Ahyani,2015:241). Dikelas unggulan siswa diberikan dengan berbagai kegiatan yang bertujuan meningkatkan kognitif, psikomotorik dan afektif siswa. Selain itu siswa kelas unggulan juga dihadapkan dengan persaingan antar teman satu kelas yang terjadi didalam kelas. Siswa kelas unggulan apabila tidak mampu mempertahankan prestasinya, akan di pindahkan ke kelas reguler. Sehingga siswa dituntut untuk selalu memiliki prestasi akademik yang baik supaya dapat bertahan di kelas unggulan. Banyak siswa yang mengaku merasa tertekan dengan tuntuan tersebut, bahkan hingga berdampak pada kesehatan jasmani siswa.

Salah satu keberhasilan siswa dalam pendidikan ditunjukkan dengan prestasi akademiknya. Keberhasilan siswa dalam pendidikannya dipengaruhi oleh motivasi berprestasi yang dimiliki. Seseorang yang memiliki motivasi berprestasi tinggi cenderung untuk selalu berusaha mencapai apa yang di inginkan walaupun mengalami hambatan dan 
kesulitan dalam meraihnya. Dalam mengatasi kesulitan tersebut, siswa memiliki kemampuan yang berbeda-beda. Ada siswa yang gagal, namun ada juga siswa yang berhasil dalam menghadapi kesulitan khususnya tuntutan untuk memiliki prestasi akademik yang baik. Motivasi berprestasi erat kaitannya dengan faktor kecerdasan individu. Selain IQ dan EQ, Adversity Quotient berperan penting untuk menyeimbangkan kedua faktor tersebut. $A Q$ yang dikonsepkan sebagai seberapa besar individu mampu dan mau untuk berjuang merupakan faktor penting yang mampu membuat seseorang memaksimalkan potensi $I Q$ dan $E Q$-nya. Sebab tanpa adanya usaha dan daya juang yang tinggi, maka $I Q$ dan $E Q$ menjadi sia - sia, tidak terpakai atau tidak bisa dimanfaatkan secara maksimal. Menurut Stoltz (2000:8) Adversity Quotient merupakan suatu kemampuan seseorang dalam mengatasi kesulitan dan mengubah kesulitan atau hambatan menjadi sebuah peluang dalam meraih kesuksesan. Adversity Quotient dipengaruhi oleh daya saing, produktivitas, kreativitas, motivasi, mengambil resiko, perbaikan, ketekunan, belajar dan merangkul perubahan (Stoltz, 2000:93). Adversity Quotient yang dimiliki oleh siswa dapat menjadi daya pendorong tersendiri yang memunculkan motivasi berprestasi dalam diri individu untuk bertahan dari tantangan dan kesulitan menjadi siswa kelas unggulan. Siswa yang memiliki adversity quotient tinggi dapat membangkitkan motif, membangkitkan daya gerak, atau menggerakkan seseorang atau diri sendiri untuk berbuat sesuatu dalam rangka mencapai suatu kepuasan atau tujuan.

Siswa yang memiliki adversity quotient yang tinggi, mampu dalam memecahkan permasalahan ataupun tantangan yang sedang dihadapi, sehingga hal tersebut akan mendorong motivasi berprestasi siswa tersebut untuk selalu ingin mencapai suatu prestasi yang ingin diraih. Akan tetapi berlaku sebaliknya jika adversity quotient yang dimiliki siswa itu rendah maka motivasi berprestasi nya pun akan rendah. Siswa akan cenderung mudah menyerah, mudah putus asa, cenderung pesimis, kurang terbuka, dan kurang bertangggungjawab.

Hasil penelitian ini juga didukung oleh penelitian yang dilakukan oleh Farelin dan Erin (2017:54) bahwa adversity intelligence merupakan salah satu faktor yang berpengaruh pada motivasi berprestasi mahasiswa; dimana diperoleh hasil nilai koefisien korelasi menunjukan nilai 0,465 dengan $p=0,000(p \leq 0,01)$. Hal ini menunjukan bahwa hasil penelitian ini signifikan. Berdasarkan penjelasan di atas, maka dapat disimpulkan bahwa mahasiswa memiliki adversity intelligence yang tinggi, sehingga segala permasalahan yang ada di kampus tidak menurunkan motivasi berprestasi yang dimiliki. 
Penelitian lain yang dilakukan oleh Kusumawati (2017:162) bahwa ada pengaruh yang signifikan antara adversity quotient terhadap motivasi berprestasi siswa kelas khusus olahraga. Hal ini dapat dilihat dari nilai R sebesar 0.668 dengan sig. $0.000(\mathrm{P}<0.05)$.

Pada penelitian ini diperoleh sumbangan efektif variabel independen penelitian yaitu adversity quotient mempengaruhi motivasi berprestasi sebesar 54,1\%, sisanya $45,9 \%$ dipengaruhi oleh variabel lain seperti seperti faktor biologis, sikap, minat, bakat, dll. Hasil penelitian ini sesuai dengan hipotesis yang diajukan, bahwa terdapat pengaruh adversity quotient terhadap motivasi berprestasi pada siswa kelas unggulan.

\section{Simpulan dan Saran}

Berdasarkan hasil penelitian yang telah dilakukan maka dapat diambil kesimpulan bahwa terdapat pengaruh Adversity Quotient terhadap Motivasi Berprestasi pada Siswa Kelas Unggulan. Semakin tinggi Adversity Quotient maka semakin tinggi juga Motivasi Berprestasi pada Siswa Kelas Unggulan, begitu sebaliknya. Sehingga hipotesis dalam penelitian ini diterima.

Saran yang dapat diberikan setelah melihat hasil penelitian, pembahasan, dan kesimpulan yang telah dikemukakan adalah sebagai berikut: Bagi siswa diaharapkan untuk terus mempertahankan kemampuan kecerdasan dalam menghadapi kesulitan (adversity quotient) karena terbukti mampu meningkatkan motivasi berprestasi. Selain itu siswa juga dapat mempertahankan adversity quotient dengan mengikuti pelatihan TELOR : Teach, Explore, Listen, Obligue,Role mode. Bagi Orangtua memiliki peran penting dalam memotivasi siswa untuk lebih berprestasi. Orangtua diharapkan mampu memberi semangat dan dorongan kepada siswa sehingga dalam menghadapi kesulitan siswa tidak merasa pesimis. Bagi pihak sekolah diharapkan dapat mempertahankan atau bahkan meningkatkan kondisi adversity quotient siswa yang secara mayoritas tergolong tinggi yaitu 80\%. Sekolah dapat memberikan pelatihan adversity quotient kepada para siswa. Bagi peneliti lain yang tertarik untuk melanjutkan penelitian diharapkan dapat melihat faktor lain baik internal maupun eksternal yang mampu mempengaruhi motivasi berprestasi pada siswa kelas unggulan seperti minat, sikap, bakat, faktor biologis, serta yang lainnya.

\section{Daftar Pustaka}


Ahyani, Nur Latifah. (2015)," Resiliensi pada Siswa Kelas Unggulan Ditinjau dari Inteligensi dan Kemandirian",Jurnal Eduscience, Vol.2, No.2,hlm.24-241.

Akbar, Reni dan Hawadi. (2001). Psikologi Perkembangan Anak. Jakarta : Grasindo.

Alberth, Supriyanto. (2015),"Hubungan Antara Motivasi Berprestasi Terhadap Hasil Belajar Matematika “. Jurnal Eduscience, Vol.1, No.1, hlm.34-38.

Azwar, saifuddin. (2011). Reliabilitas dan Validitas.Yogyakarta : Pustaka Belajar. (2017). Metode Penelitian Psikologi. Yogyakarta : Pustaka Pelajar.

Djaali. (2015). Psikologi Pendidikan. Jakarta : Bumi Aksara.

Farelin dan Erin. (2017). "Hubungan Antara Adversity Intelligigence Dengan Motivasi Berprestasi Pada Mahasiswa".Jurnal Empati,Vol.6, No.2, hlm.48-54.

Hamdani. (2011). Strategi Belajar Mengajar. Bandung : Pustaka Setia.

Huda, Tesa N dan Agus Mulyana. (2017)," Pengaruh Adversity Quotient Terhadap Prestasi Akademik Mahasiswa Angkatan 2013 Fakultas Psikologi UIN SGD Bandung”, Jurnal Ilmiah Psikologi, Vol.4, No.1, hlm.131-133.

Jamaris, Martinis. (2013), Orientasi Baru Dalam Psikologi Pendidikan. Bogor: Ghalia Indonesia.

Khusnayain, Dini. (2015),“ Manajemen Pembelajaran Kelas Unggulan di MTs Muhammadiyah Blimbing Tahun Pelajaran 2014/2015", Jurnal Eduscience, Vol.4, No.1, hlm.34-36.

Kusumawati, Dwi. (2017),“ Pengaruh Adversity Quotient, Regulasi Diri Dan Efikasi Diri Terhadap Motivasi Berprestasi Siswa Kko Smp Negeri 13 Yogyakarta”.Jurnal Pendidikan Agama Islam,Vol.14, No.1, hlm.162-163.

Mangkunegara, Prabu. (2010). Perilaku dan Budaya Organisasi. Bandung :Refika Aditama.

Patricia, Zamralita dan Ninawati. (2009)," Adversity Intelligent Dan Prestasi Kerja Karyawan PT. X, Jurnal Ilmiah Psikologi Industri dan Organisasi ", Vol.11, No.1, hlm.66-67.

Periantalo, Jelpa. (2016). Penelitian Kuantitatif Untuk Psikologi. Yogyakarta : Pustaka Pelajar.

Putra, Hidayati dan Nurhidayah. (2016)," Hubungan Motivasi Berprestasi Dengan Adversity Quotient Warga Binaan Remaja di LPKA Kelas II Sukamiskin Bandung “, Jurnal Pendidikan Keperawatan Indonesia, Vol.2, No.1, hlm.55-59.

Sopiatin dan Sahrani, (2011). Psikologi Belajar dalam Perspektif Islam. Bogor : Ghalia Indonesia.

Stoltz, Paul G. (2000). Adversity Quotient. Jakarta : Gramedia Widiasarana. . (2007). Adversity Quotient. Jakarta : Grasindo. 
Philanthropy Journal of Psychology

Vol 4 Nomor 1 (2020), 82-92

ISSN 2580-6076 (Print), ISSN 2580-8532 (Online)

Stoltz, Paul dan Weihenmayer.(2010). Adversity Advantage.

Wijilestari, Nunik. (2013)," Klasifikasi Siswa Kelas Unggulan Menggunakan Fuzzy CMeans",Jurnal Eduscience, Vol.5, No.1,hlm.103-104. 